УДК 622.271 .3

DOI https://doi.org/10.32838/2663-5941/2020.4/41

Савчук Л.В.

Національний університет «Львівська політехніка»

Доскіч С.В.

Національний університет «Львівська політехніка»

\title{
РЕВІТАЛІЗАЦІЯ ТЕРИТОРІЇ ВІДПРАЦЬОВАНИХ ЯЗІВСЬКОГО ТА НЕМИРІВСЬКОГО РОДОВИЩ СІРЧАНИХ РУД
}

Надмірне споживання природних ресурсів спричинило утворення великої кількості порушених земель, непридатних для використання. У зв'язку з ичи у середині минулого століття виник новий науково-технічний напрям - рекультивачія, щзо передбачає повернення порушених територій до початкового або близького до початкового стану. Відкриття потужних родовищ сірчаних руд на Львівщчині в 50-х роках минулого століття дало потужний поштовх розвитку видобутку сірки і виробництву низки продуктів хімічної промисловості. Вичерпання руд із високим вмістом сірки, економічна недоцільність використання бідних руд, нарощування видобутку дешевої сірки, яку отримували як побічний продукт очшщення природного газу та нафти від сірковмісних сполук, спричинило припинення видобутку сірки i закриття підприємств хімічної галузі, щзо базувалися на території родовищ. Було проведено рекультивацію території родовищ сірчаних руд - Язівського та Немирівського з утворенням найбільшої штучної водойми Львівщини Яворівського озера. Мета роботи - моніторинг стану рекультивованої території Язівського та Немирівського родовищ сірчаних руд для їх повночінного використання. Це дасть змогу забезпечити екологічну безпеку, попередити надзвичайні ситуації та науково обгрунтувати рішення ефективного господарського освоєння відновлених територій. Проведені дослідження показали, щуо в початковий період затоплення мінералізація води на поверхні озера була досить висо-

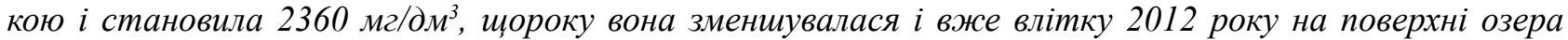
вода була прісною (969 мг/дм³). 32012 року якість води погіршується, з 2013 року опріснення озера припинилося. У липні 2015 року спостерігалося підвищення мінералізацї води на поверхні озера до

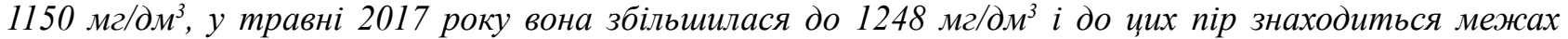
1248-1280 мг/дм . Вода в озері належить до кальиій-сульфатних, із високим значенням твердості і дуже високим вмістом сульфатів, щзо можна пояснити розчиненням гіпсоангідритів та вапняку. На початкових стадіях затоплення спостерігали високий вміст сірководню, в останніх пробах до глибини 30 м ия токсична домішка відсутня. Прозорість води в озері - 8 м. Після добування сірки грунти забруднені сіркою, вміст якої зменшується з глибиною, в шарі трунту до 20 см 2-3\%, на глибині 20-40 см 0,4-0,6\%. Змінився і рН грунтів, він становить 3-4, а на деяких ділянках - 1,5-2. Для відпрацььованих територій характерне вторинне засолення грунтів, вони стали біотоксичними. Водночас у прибережній зоні велика кількість озерної рослинності, уже водиться риба. Яворівське озеро має всі необхідні умови для організації на його базі регіонального ичентру рекреації.

Ключові слова: рекультивація, ревіталізація, техногенно порушені землі, постмайнінг, рекультивачія, водні ресурси.

Постановка проблеми. У своєму розвитку людство завжди намагалося підкорити природу будь-яким шляхом, надмірно споживаючи ii ресурси і руйнуючи все, що його оточувало. Надмірне споживання стало моделлю суспільного розвитку. Це призвело до вичерпування природних ресурсів: вирубки лісу, виснаження родовищ корисних копалин, надмірного споживання та забруднення води, руйнування земельного фонду тощо. Таке ставлення до довкілля спричинило забруднення Землі відходами (твердими, рідкими, газоподібними), порушило баланс при- родних процесів. Минулого століття внаслідок бурхливого промислового розвитку в Україні загалом і Львівській області зокрема розробляли велику кількість родовищ корисних копалин і добували природну сірку, калійні солі, вугілля, залізні, уранові, нікелеві, титанові руди тощо. Родовища природної сірки Львівської області належали до найпотужніших у світі. Але за роки експлуатації багатші руди були використані, а 3 нижчим вмістом сірки переробляти було економічно не доцільно. Крім того, нарощувався видобуток дешевої сірки, яку отримували як побічний 
продукт очищення природного газу та нафти від сірковмісних сполук і яка коштувала 25-35 доларів проти 100-120 за перероблення сірчаних руд. Тому в 1997 році було прийнято рішення про закриття найбільшого у світі Яворівського сірчаного кар'єра. У басейні р. Вісла утворилися величезні території порушених земель, непридатних для сільськогосподарського використання через їх забруднення сіркою та іншими шкідливими речовинами. Відновлення цих територій стало важливою проблемою, що вимагала негайного вирішення.

Аналіз останніх досліджень і публікацій. Сучасні реалії вимагають нових підходів до рекультивації порушених земель - їх відновлення і створення умов для відродження життя у всіх його проявах природним шляхом. Цього досягають ревіталізацією (відродженням) природного середовища, а саме: відслідковуванням процесів, що протікають на рекультивованих землях, прогнозуванням змін та наданням рекомендацій щодо управління процесами відновлення для забезпечення високої якості життя.

Одним із шляхів зменшення негативного впливу техногенних процесів на довкілля $\epsilon$ рекультивація земель. Це науково-технічний напрям, що виник порівняно недавно і передбачає повернення порушених територій до початкового або близького до початкового стану. Проблемами рекультивації порушених земель займалися багато українських та зарубіжних учених. Серед них - В. Кнабе, І. Лазарева, Б. Колесников, С. Трофимов, Л. Моторина, В. Овчинников, Б. Волосецький, Р. Панас, А. Гайдін, I. Зозуля, М. Маланчук. Процесами рекультивації пост техногенних територій на заході України займалися і займаються науковці Львівського інституту гірничо-хімічної промисловості, які розробили і втілили в життя низку проектів щодо відновлення порушених земель [1, с. 29, 32; 2, с. 12].

Для проведення комплексу робіт із рекультивації порушених земель розроблено ДСТУ 7705:2015 Захист довкілля. Рекультивація земель. Терміни та визначення понять. Метою рекультивації є повернення порушених земель до ефективного використання в народному господарстві. Вибір відповідних заходів для відновлення порушених земель залежить від: природних умов району, стану порушених земель, характеристики складників території, інженерно-геологічних, гідрологічних, господарських, соціально-економічних та екологічних умов, технології і механізації гірничих і будівельно-монтажних робіт тощо. На вибір виду рекультивації впливає агрохімічний склад грунтів і розривних порід, географічне розташування, соціально-економічні чинники, перспективи розвитку території [3, с. 16].

3 огляду на сучасний стан екології та спровоковану ним зміну клімату, для повернення території, зайнятої порушеними землями до ефективного використання, використовують процес ревіталізації $[4$, с. 9]. Це поняття ширше ніж рекультивація і охоплює не тільки постмайнінг, але й постійне спостереження і контролювання стану відновлених земель і складників території та прогнозування подальших змін. Автори $[4$, с. 10] під постмайнінгом розуміють комплекс робіт, що проводять після завершення експлуатації родовища корисних копалин, який включає демонтаж обладнання, ліквідацію гірничих виробок, впорядкування гідромережі, планувальні роботи на ділянках, придатних для рекультивації. Моніторинг необхідний для ефективного управління процесами відновлення порушених земель та запобігання негативних проявів шкідливих чинників, що мали місце під час гірничо-промислових розробок.

Відродження посттехногенних територій є світовою проблемою. Так, після обвального падіння цін на сірку уряд Польщі прийняв рішення про закриття сірчаного кар'єра Махув і його перетворення на озеро для рекреації. Роботи фінансувалися 3 державного бюджету, виконувалися фахівцями Науково-дослідного центру «Сяркополь» і Гірничо-металургійною академією [5, с. 48].

Великий обсяг роботи виконали вчені Німеччини, які відразу після падіння Берлінської стіни провели рекультивацію солевидобувних та буровугільних кар'єрів, створивши озера, парки, пляжі, різні атракціони, дитячі майданчики, станції човнів [6, с. 167]. Починаючи з 2016 р. світова наукова спільнота постійно проводить міжнародні конференції, на яких розглядає способи (шляхи, напрями) поводження із закинутими шахтами та кар'єрами.

Постановка завдання. Величезні території порушених земель, утворені внаслідок розробки родовищ сірчаних руд на Львівщині, рекультивували, створивши штучну водойму, призначену для рекреаційного та господарсько-побутового використання. На стан території довкола водойми - грунтів, води, тваринного і рослинного світу тощо - впливає швидкість і якість процесів відновлення. Тому метою досліджень є моніторинг стану рекультивованої території Язівського та Немирівського родовищ сірчаних руд для їх повноцінного використання. 
Виклад основного матеріалу дослідження. Процеси індустріалізації та урбанізації негативно впливають на навколишнє природне середовище. Тому першочерговим завданням $\epsilon$ шляхи зменшення негативного впливу техногенних процесів на довкілля. Водночас одним із показників високого рівня життя $є$ здоров'я населення, на яке впливають умови рекреації, якість питної води і таке інше. Тому, розглядаючи можливості рекультивації земель Язівського та Немирівського родовищ сірчаних руд, брали до уваги стан території і склад грунтів до початку видобутку сірки та можливості відновлення порушених земель для сільськогосподарського виробництва чи для рекреації. До відкриття в 1956-1957 рр. родовищ самородної сірки територія Яворівщини була вкрита мішаними лісами, за винятком болотистих ділянок у заплавах річок. Тут були розвинуті потужні четвертинні відкладення, представлені флювіогляціальними пісками. Вони містили водоносний горизонт прісної води високої якості. Грунтові води залягали на глибині 2-3 м, а в долинах $-0,5-1 \mathrm{м}$.

На Язівському родовищі сірчаної руди природну сірку видобували в основному методом підземної виплавки та частково кар'єрним способом. Немирівське родовище розробляли підземною виплавкою. Розробка сірчаних родовищ супроводжувалася ландшафтними змінами: вилученням земель із господарського обігу, створенням техногенних ландшафтів, забрудненням грунтів сіркою, вирубкою лісів, створенням системи примусового відведення річок із території родовища будівництвом дамб, каналів, водосховищ. Після добування сірки грунти були забруднені ії залишками та іншими шкідливими домішками, що негативно впливають на якість грунтових вод. Вміст сірки в шарі грунту до $20 \mathrm{~cm}-2-3 \%$, на глибині $20-40 \mathrm{~cm}$ зменшується до 0,4-0,6\%. Змінився і $\mathrm{pH}$ грунтів: становить 3-4, а на деяких ділянках $-1,5-2$. Для відпрацьованих територій було характерне підтоплення грунтів, що супроводжується вторинним засоленням. Грунти стали біотоксичними, а їх самоочищення без вживання спеціальних рекультиваційних заходів триватиме до $15-25$ років. 3 огляду на вищевикладене і досвід із рекультивації таких територій у Польщі [5, с. 52], найбільший елемент техногенного ландшафту - Яворівський сірчаний кар'єр - було затоплено, а отриману водойму рекомендовано використовувати для рекреаційних цілей, а за потреби - для господарсько-питного водопостачання. Тому моніторинг стану території в межах найбільшої штучно створеної водойми Львівщини $є$ дуже важливим.
Яворівський сірчаний кар'єр був котлованом, частково заповненим внутрішніми відвалами. Розміри поверхні $-3300 \times 2700$ м, дна $2000 \times 2200$ м. Площа порушених земель по поверхні (по четвертинних відкладах) - 847 га, по третинних глинах - 525 га, по руді - 332,6 га, внутрішніх відвалів - 287,3 га. Практично по всьому периметру кар'єра внутрішні відвали відмежовані від борта кар'єра траншеєю глибиною 20-30 м і шириною в нижній частині в середньому 50 м. Винятком $є$ лише західний борт Південного кар'єра. У центрі східного борта кар'єра була прокладена виїзна траншея. Її продовженням була розрізна траншея, яка розмежовувала Центральний і Південний кар'єри. Тут проходила рудовозна дорога.

До початку затоплення кар'єра найнижчі відмітки були в районі центрального зумпфу $(130 \times 130$ м), який був розташований поблизу виїзної траншеї. На північ від нього знаходився північний зумпф, а з західної сторони центрального кар'єра - західний зумпф. Рівень води, відповідно, мав позначки 150-151 м, 153-154 м, 158-159 м. Відмітки підошви рудного покладу на східному фланзі Центрального кар'єра в основному знаходились у межах 146-150 м, в центрі кар'єра - 152-156 м, на західному фланзі - 155-160 м. Мінімальна позначка підошви на Південному кар'єрі 155,8 м, і вона підвищується від центру до флангів. Найбільші відмітки вершин внутрішніх відвалів сягають 215-230 м. Схили внутрішніх відвалів відповідають куту природного схилу і місцями сповзають. Глибина Центрального кар'єра вздовж західного борта $-60-70$ м, у центрі -80 м, в районі центрального зумпфу - до 90 м, в північно-західній частині - до 105 м. Глибина Південного кар'єра - 50-70 м. Залишкова ємкість кар'єра дорівнює 307 млн м².

Внаслідок ліквідації та рекультивації Яворівського кар'єра 3 видобування сірки, затоплення водою утворилася найбільша штучна водойма Львівської області, створена за проектом Львівського інституту «Гідрохімпром». Оскільки кар'єр перетинав басейн річки Шкло з притоками Гноєнець, Терешка та інші, в період експлуатації для відведення річок була створена складна система водовідведення. Згідно 3 проектом, який вже втілено в життя, передбачено відновлення річкового стоку з метою повернення річок у кар'єр i для подальшого витоку води з майбутнього озера старим руслом річки Шкло.

Заповнення кар'єра водою р. Шкло відбувалось в 2002-2006 роках. 
Яворівський сірчаний кар'єр затоплений підземними, поверхневими і річковими (р. Шкло, p. Якша, р. Гноєнець) водами. Його максимальна глибина сягає 75 м у районі Центрального зумпфа. Глибина озера в районах видобувних зон сірчаної руди - 50-60 м, а в межах внутрішніх відвалів розташовані менш глибокі ділянки з глибиною 10-30 м. Об'єм озера становить 198 млн м ${ }^{3}$ при площі дзеркала води 694,2 га.

Озеро живиться з таких джерел: атмосферних опадів на площі водного дзеркала та прибережної водозбірної площі; води річок Гноєнець, Шкло і Якша; підземних вод неогенового водоносного комплексу, мінералізація яких становить біля 2700 мг/л.

У період експлуатації річка Шкло була забруднена стічними водами з технологічного комплексу. Після припинення його роботи пройшло самоочищення. Річкові води за вмістом основних компонентів відповідають нормативам для питної води. На витоку води з водосховища Новий Яр загальна мінералізація води становить $417 \mathrm{мг} /$ дм³ $^{3}$, вміст сульфатів - 97 мг/дм³ ${ }^{3}$ фосфати відсутні. Однак у канал впадають забруднені стоки з санаторію Шкло i 3 промзони, що розташована поблизу управління колишньої виробничого об'єднання «Сірка». У воді, що витікає з території санаторію Шкло, присутні сполуки азоту і фосфору, які свідчать про органічне забруднення.

У період затоплення кар'єрної виїмки мінералізація води на поверхні озера 3 кожним роком зменшувалася. На початку затоплення вона становила 2360 мг/дм³ [7, с. 58], наприкінці (2006 рік) 1200 мг/дм³ [8, с. 122]. У період трансформації (першого водообміну) мінералізація продовжувала зменшуватися і влітку 2012 року на поверхні озера вода була вже прісна (969 мг/дм³). 32012 року якість води погіршується, з 2013 року опріснення озера припинилося. У липні 2015 року виявлено підвищення мінералізації води на поверхні озера до $1150 \mathrm{мг/дм³} \mathrm{,} \mathrm{в} \mathrm{травні} 2017$ року вона збільшилася до 1248 мг/дм². У каналі на витоку з озера мінералізація становила 1377 мг/дм³ . Прозорість води в озері $-8,0$ м. Практично стабільним був вміст іону калію в озерній воді (від 4.5 до $11 \mathrm{мг/дм³} \mathrm{в} \mathrm{усій} \mathrm{товщі} \mathrm{озерної} \mathrm{води)} \mathrm{і} \mathrm{вміст} \mathrm{хлор-}$ іону (від 19 до 27 мг/дм³).

Хімічний склад води Яворівського озера в 2017 році наведено в таблиці 1.

Як видно з таблиці, в поверхневому шарі мінералізація води становить 1248 мг/дм³ , а в каналі на витоку з озера - 1377 мг/дм³ нормативні показники для питного водопостачання і для умов випуску води в гідромережу. Вода характеризується високим значенням твердості, що можна пояснити розчиненням гіпсоангідритів та вапняку. Ці мінерали не тільки активно відшаровувалися з бортів кар'єра на початку його затоплення, але й потрапляли у воду з внутрішніх відвалів, якими був заповнений кар'єр.

Негативним є забруднення води в озері сульфатами, кількість яких із глибиною зростає. Це, на нашу думку, пов'язане не тільки 3 хімічними процесами і розчиненням гіпсоангідридів, але й із діяльністю сульфатредукуючих бактерій. Якщо на початкових стадіях затоплення спостерігали високий вміст сірководню, то в останніх пробах до глибини 30 м ця токсична домішка відсутня. Це можна пояснити збільшенням води у водоймах (фактор розведення) й окисненням зеленими та пурпуровими сіркобактеріями.

Таблиця 1

Хімічний склад води Яворівського озера (мг/дм³)

\begin{tabular}{|c|c|c|c|c|c|c|c|c|c|c|c|}
\hline $\begin{array}{c}\text { Глибина, } \\
\text { м }\end{array}$ & pH & $\mathbf{N a}^{+}$ & $\mathrm{Ca}^{2+}$ & $\mathbf{M g}^{2+}$ & $\mathrm{HCO}_{3}^{-}$ & $\mathrm{SO}_{4}{ }^{2-}$ & $\mathrm{NO}_{3}^{-}$ & $\mathbf{P}_{2} \mathbf{0}_{5}$ & $\mathrm{H}_{2} \mathrm{~S}$ & $\mathbf{N H}_{4}^{+}$ & $\begin{array}{l}\text { Заг. } \\
\text { мін. }\end{array}$ \\
\hline 0 & 6,9 & 29.7 & 290 & 6,1 & 173 & 710 & 5,1 & 0,0 & 0 & 2,1 & 1248 \\
\hline 5 & 7,5 & 29.5 & 310 & 2,4 & 175 & 759 & 5,1 & 0,0 & 0 & 1,7 & 1314 \\
\hline 10 & 7,5 & 29.7 & 300 & 2,4 & 170 & 995 & 5,8 & 0,0 & 0 & 2,5 & 1538 \\
\hline 20 & 7,3 & 32.4 & 308 & 1,2 & 168 & 948 & 5,7 & 1,1 & 0 & 1,8 & 1500 \\
\hline 30 & 6,6 & 35.9 & 340 & 13,4 & 373 & 1502, & 6,8 & 17,2 & 20,2 & 8,4 & 2352 \\
\hline 40 & 6,6 & 38,5 & 332 & 4,9 & 368 & 1546 & 8,8 & 17,8 & 24,8 & 9,3 & 2386 \\
\hline 50 & 6,6 & 41,1 & 336 & 2,4 & 383 & 1333 & 9,5 & 18,2 & 21,7 & 8,7 & 2188 \\
\hline 60 & 6,6 & 41,9 & 330 & 4,9 & 370 & 1332, & 17,7 & 12,1 & 20,7 & 7,6 & 2174 \\
\hline 70 & 6,6 & 42,5 & 338 & 4,9 & 358 & 1571 & 19,1 & 13,9 & 22,7 & 7,9 & 2415 \\
\hline 82 дно & 6,6 & 43,0 & 348 & 6,1 & 441 & 1308 & 16,1 & 33,1 & 28,4 & 17,3 & 2280 \\
\hline Заток. р. Шкло & 7,7 & 13,5 & 246 & 8,5 & 175 & 377 & 7,2 & 0,0 & 0 & 1,9 & 856 \\
\hline $\begin{array}{l}\text { Впад. p. Шкло } \\
\text { в озеро }\end{array}$ & 7,4 & 17,5 & 102 & 6,1 & 205 & 389 & 4,4 & 0,0 & 0 & 0,0 & 750 \\
\hline Витік з озера & 7,8 & 37 & 326 & 45 & 168 & 769 & - . & 0,4 & 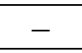 & $\begin{array}{llll}- & & & \\
\end{array}$ & 1377 \\
\hline
\end{tabular}


За останніми дослідженнями, вода Яворівського озера належить до такої, яка вважається чистою, солонуватою. Мінералізація води в поверхневій зоні стабілізувалася на рівні 1,3 г/дм³ , сірководень відсутній. Подальше опріснення води можливе після завершення впускної споруди на річці Гноянець і осушенні водосховища Новий Яр, як це передбачено проектом. За даними Львівського управління охорони природи, вода техногенних водоймищ - ставків на річках у зоні діяльності колишнього Яворівського ДГХП «Сірка» відповідає якості природних вод цього регіону, і ці водоймища використовуються місцевим населенням. Нині площа озера близько 10 км², довжина берегової лінії - до 12 км. Рельєф дна є таким: максимальна глибина приблизно 70 м, $\epsilon$ мілини з підводною і надводною рослинністю, затоплені пагорби, багато затоплених кущів та дерев. У прибережній зоні велика кількість озерної рослинності. Уже водиться риба: щука, плітка, карась, сазан, окунь, товстолобик, лин (на мілинах і в заростях тростини).

Яворівське озеро має всі необхідні умови для організації на його базі регіональних центрів рекреації. Необхідно прискорити освоєння рекреаційного потенціалу цього озера, що дасть змогу створити прибуткові підприємства та нові робочі місця.

Висновки. Високий рівень використання природних ресурсів супроводжується вичерпанням ïх запасів і утворенням порушених ландшафтів, які варто повертати в оббіг, гармонійно вписуючи в довкілля відповідно до естетичних вимог. Для цього треба використовувати концепцію ревіталізації порушених територій - повернення до життя у всіх його проявах.

Ревіталізація території відпрацьованих Язівського та Немирівського родовищ сірчаних руд 3 утворенням штучної водойми - Яворівського озера $є$ наочним прикладом повернення порушених земель до ефективного використання. Яворівське озеро може використовуватися як для відпочинку та спорту, так і для забезпечення населення питною водою.

Для забезпечення екологічної безпеки, попередження надзвичайних ситуацій та науково обгрунтованого ефективного господарського освоєння відновлених територій необхідно проводити їх постійний моніторинг.

\section{Список літератури:}

1. Гайдін А.М., Зозуля І.І. Яворівське озеро. Львів : ПТВФ «АФІША», 2007. 56 с.

2. Гайдін А.М., Зозуля І.І. Ландшафтний парк «Подорожне». Львів : ПТВФ «АФІША», 2010. 37 с.

3. Панас Р.М. Рекультивація земель : навч. посібник. Львів : Новий світ, 2007. 224 с.

4. Гайдін А.М., Собко Б.Ю. Ревіталізація. Відновлення порушених ландшафтів в зонах діяльності гірничих підприємств : монографія / А.М. Гайдін, Б.Ю. Собко. Дніпро : ПП Кулик В.В., 2019. 218 с.

5. Gawlik B., Kopec J. Zagadnenia likwidacji wyrobyska kopalni siarki Machow w procesach restukturizacji przemzslu siarkowego. Kstaltowanie krajobrazu terenow posteksploatacyjnych w gornictwe. Krakow, 2003. $367 \mathrm{p}$.

6. Thoma H., Seifert G., Kuehn F. Examoles of the development of sinkholes above flooding or flooded salt mines in central Germany and ways of remote detection of areas with potencial risk of fal. Fall 2000 Miting. San Antonio, Texas, USA, 2000. P. 163-175.

7. Баран I.М., Подопригора О.І., Грищук Г.В., Боднар Л.С., Кіт Л.Я., Клим I.Р., Гнатуш С.О., Гудзь С.П. Екологічний моніторинг водойм Яворівського сіркового родовища; мікробіологічний контроль. Довкілля та здоров'я. 2003. № 4 (27). С. 56-62.

8. Гайдин А.М. Формирование химического состава воды при затоплении серных карьеров. Геоэкология. Инженерная геология. Гидрогеология. Геокриология. 2008. № 2. С. 118-123.

\section{Savchuk L.V., Doskich S.V. TERRITORY REVITALIZATION OF THE SPENT YAZIVSKY AND NEMYRIVSKY SULFUR ORE DEPOSITS}

Excessive consumption of natural resources led to the formation of a large number of disturbed lands unusable. As a result, in the middle of the last century, a new scientific and technical direction emergedreclamation, which involves the return of disturbed territories to their initial or close to the initial state. The discovery of powerful deposits of sulfur ores in the Lviv region, in the 50s of the last century, gave a powerful impetus to the development of sulfur production and production of a number of chemical products based on it. Depletion of high-sulfur ores, economic inexpediency of using poor ores, increasing production of cheap sulfur, which was obtained as a by-product of purification of natural gas and oil from sulfur-containing compounds, led to the cessation of sulfur production and closure of chemical plants based on deposits. It was carried out the reclamation of the territory of sulfur ore deposits - Yazivsky and Nemyrivsky with the formation of the largest artificial reservoir of Lviv region Yavoriv Lake. The purpose of the work is monitoring of the reclaimed territory condition of Yazivsky and Nemyrivsky sulfur ore deposits for their full use. This will 
ensure environmental safety, prevent emergencies and scientifically justify the decision of effective economic development of restored territories. Conducted studies have shown that in the initial period of flooding the water mineralization on the surface of the lake was quite high and amounted to $2360 \mathrm{mg} / \mathrm{dm}^{3}$, every year it decreased and already in the summer of 2012 on the surface of the lake the water was fresh $\left(969 \mathrm{mg} / \mathrm{dm}^{3}\right)$. Since 2012, water quality has deteriorated, since 2013; the desalination of the lake has stopped. In July 2015, there was an increase in water mineralization on the surface of the lake to $1150 \mathrm{mg} / \mathrm{dm}^{3}$, in May 2017 it increased to $1248 \mathrm{mg} / \mathrm{dm}^{3}$ and is still in the range of $1248 \ldots 1280 \mathrm{mg} / \mathrm{dm}^{3}$. The water in the lake is calcium sulfate, with a high value of hardness and a very high content of sulfates, which can be explained by the dissolution of gypsum anhydrite and limestone. In the initial stages of flooding, a high content of hydrogen sulfide was observed, in recent samples up to a depth of 30 meters, this toxic impurity is absent. The transparency of the water in the lake is $8,0 \mathrm{~m}$. After extraction of sulfur, the soils are contaminated with sulfur, the content of which decreases

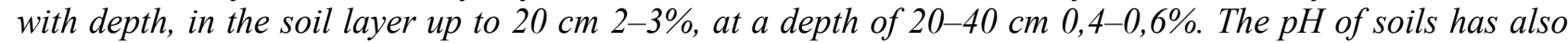
changed, it is 3-4, and in some areas - 1.5-2. Spent territories are characterized by secondary salinization of soils, they have become biotoxic. At the same time, there is a large amount of lake vegetation in the coastal zone, and fish are already found. Yavoriv Lake has all the necessary conditions for the organization on its basis the regional recreation center.

Key words: reclamation, revitalization, technogenic disturbed land, post mining, water resources. 